\title{
Implementation of the Therapeutic Community for Convicts in Indonesian Correctional Institution
}

\author{
Andari Rizky Aria Putra ${ }^{1^{*}}$ \\ ${ }^{1}$ Politeknik Ilmu Pemasyarakatan \\ *Corresponding author, e-mail: andariganoci198@gmail.com
}

Received 2020-03-24;

Revised 2020-04-28;

Accepted 2020-05-02;

Published Online 2020-05-30

\section{Conflict of Interest}

Disclosures:

The authors declare that they have no significant competing financial, professional or personal interests that might have influenced the performance or presentation of the work described in this manuscript.

\begin{abstract}
The increase in drug abuse, psychotropic drugs, and other illegal drugs in Indonesia has an impact on increasing the number of drug convicts. At the Rehabilitation Institute, convicts will be guided using Community Therapy procedures aimed at rehabilitating convicts. The purpose of this study is to describe the implementation of the Therapeutic Community in the implementation of coaching that can be a reference in the implementation of coaching in the Indonesian Penitentiary. The literature review study was carried out by analyzing several documents related to the implementation of the therapy community for drug prisoners, commonly the Indonesia role of law related. The results of this study conclude that the implementation of the Therapeutic Community in Penitentiary in Indonesia supports various parties in its implementation in order to run well, but in reality the field still has some obstacles in implementing the Therapeutic Community.
\end{abstract}

Keywords: Therapeutic community, narcotic abuse, correctional institution, drugs rehabilitation.

\section{Introduction}

Todays the development of science and technology has created various social problems. One of the social problems is the misuse of drugs (Taman et al., 2002). Cases that occur in Penitentiaries have always surfaced the last few (Jacobs, 2015). The public is always faced with news about drugs which always attracts the media to be appointed (Babor, et al., 2020). As we know, occurred in 2019 faced with the arrest of drug cases by Indonesian artists in her residence in the Tebet area. According to data from the arrest detikNews there is evidence of ownership of 0.36 grams of methamphetamine that is stored in a drawer. 
The other sample is the incident in 2019, faced again with the capture of the Ibra Azhari drug case in South Jakarta, the arrest began with a public report of the existence of a drug transaction, with the report the police jumped into the field who discovered the fact that there were couriers that sell methamphetamine to Ibra Azhari which in his confession for personal consumption, this is the 4th case of Ibra. Followed again by the arrest of the controversial drug case against Lucinta Luna celebrity. The arrest also began with a public report which was later investigated by the police. Lucinta was secured in her apartment in central Jakarta on Tuesday 11 February 2020 with evidence of a number of riklona, tramadol in her bag. Some of these cases surfaced in the past year not to mention with a number of other small cases that should be in particular concern to the Ministry of Law and Human Rights of the Republic of Indonesia in handling them.

With the cases that are always faced by the ranks of the Indonesian Ministry of Justice and Human Rights under the Directorate General of Corrections (in Nurfatiha, 2015), who take care of Lapas throughout Indonesia becomes a serious problem that must be faced and need to be evaluated against various issues. The problem that is always faced is certainly there are fundamental things faced by the Corrections staff both in the direction of policies and management of prisons that must be addressed.

According to Indonesia Law Noumber 35 of years 2009, Narcotics are substances or drugs of Indonesia (BNN) derived from plants or non-plants, both synthetic and semisynthetic, which can cause a decrease or change of consciousness, loss of taste, reduce to eliminate pain, and can cause dependence, which is differentiated into groups as attached to this Law. This substance can reduce to eliminate taste and reduce dependence. Based on the statement of the Head of BNN narcotics users in Indonesia increased to 3.6 million. That was confirmed by fiew of surces, such as Ismail et al (2015); Morison, et al (2012).

The increasing in narcotics abuse not only has a negative impact on victims. In addition to the impact on victims, narcotics abuse also affects families, the community, the economy, even to the point of causing other social problems, namely the increasing number of prisoners of Narcotics cases in Corrections.

Correctional Institution is one of the Correctional Technical Implementation Units that serves as a place for inmates and correctional students. In addition, LAPAS also functions as a forum to cure lawbreakers, not as a place for retaliation / torture (Detterance). This is in line with the goals of Correctional Institutions, namely to form Correctional Prisoners (WBP) to become fully Indonesian people, realize mistakes, improve themselves and no longer repeat crimes so that they can be re-accepted by the community, can actively play a role in development and can live reasonably as a good and responsible citizen. This was not only influenced by internal institutions in the Republic of Indonesia Ministry of Law and Human Rights but also influenced by external institutions such as policy relations with other relevant ministries or institutions, such as in the regulation of narcotics users (social and medical rehabilitation), which were still in prison so that prisons and over-experienced crowded due to prisoners with rehabilitation decisions drug cases are still in prison.

Besides that, from the coordination factor with other institutions / agencies namely the Police, Attorney's Office, Courts, National Narcotics Agency (BNN), National Counterterrorism Agency (BNPT), Legislative Institution (DPR RI) and with NGOs, this also needs synergy coordination for overcome problems that occur in prisons. Coordination must be in line with the programs in Lapas so that every policy is well integrated in overcoming various problems that arise in Lapas. Coordination and consultation have been carried out by a number of these state institutions, but they have not been sufficiently optimal to anticipate problems that occur in prisons, so it needs policies that contribute to the management of prisons.

Fixing problems in narcotics abuse is not an easy problem. It takes a long time and serious attention, one form of serious government attention is through the Penal System in Article 3 of Law No. 12 of 1995 concerning Corrections explains that the Correctional Function is to prepare Correctional Fostered Citizens so that they can integrate in a healthy manner with the community, so that they can play a role as free and responsible community members again. can be accepting by the community is through the guidance process in Lapas.

One of the programs in corectional institution (LAPAS) is to improve drug addicts to run a therapeutic community program, also known as TC. The Therapeutic Community concept found by M. Jones. The Therapeutic Community was led by former drug addicts who have recovered and have attended counselor training. Therapeutic Community is a form of social therapy or milleu therapy, milleu therapy is a therapy 
that is carried out by creating a new environment that systematically uses daily routine as a pattern to deal with problems that concern the emotions and behavior of individuals.

Therapeutic Community (TC) has the motto "Man helping man to help himself". Community members (residents) are responsible for helping one another, by helping others as well as helping themselves. This community which helps each other is believed to be able to return an addict to the right life (right living). Based on the journal drug abuse (UNDPC, 1990), the Therapeutic Community method has a success rate of $80 \%$ with its indicators, the abuser succeeds in surviving the substance-free condition (abstinensia) for a longer time, with the record that the resident follows all the stages to completion.

The TC program is a drug addiction rehabilitation program in Indonesia that has been taking place since 1997, initiated by families of drug addicts. The basic approach of TC is to carry out therapy to individuals as a whole. Therefore, researchers are interested to know the development of community therapy program as one of the recovery programs for resident drug addicts that is implemented by evaluating a therapeutic community program.

\section{Method}

This study is a literature review that examines documents related to the application of community therapy to drug convicts. Descriptive qualitative based on the main library (Thomas \& Magilvy, 2011), especially the law in force in Indonesia. A literature study is conducted to study primary legal materials in the form of laws, secondary legal materials in the form of literary books, articles accessed via the internet, newspapers, and legal opinions from sources relating to the implementation of independence development programs in correctional institutions. The qualitative data analysis procedure was carried out in order to find the meaning and stigma formed about drug prisoners and their rehabilitation efforts (Ritchie \& Spencer, 2002).

\section{Results and Discussion}

\section{A. Implementation of Therapeutic Community Against Drug Prisoners}

The TC program that can be implemented at the Indonesian Penitentiary is adapted from the TC implementation of the Drug Rehabilitation Institutions / Institutions in Indonesia, which refer to the guidelines for the implementation of drug rehabilitation laid out by the Indonesian Ministry of Social Affairs (Kementerian Sosial Republik Indonesia) and the National Narcotics Agency (BNN). However, not all activities in the TC program can be carried out purely within prisons. This is due to differences in conditions and functions of prisons and rehabilitation agencies.

Schedule for regular activities is carried out every Monday to Friday from 09.30-12.00 WIB and then continued from 14.00-16.00 WIB. Until now the program that has been run is the Primary program. In addition to regular activities in the TC program, there is also a special training for approximately 1 month for 'Peer Counselor' candidates. The participants are family members who have finished participating in regular TC activities and successfully passed the assessment selection process. To date there have been 15 Peer Counselors who assist with the daily TC activities. As for becoming a Peer Counselor, you must have the following conditions:

1) Has finished the primary program

2) Shows positive progress

3) Passed the selection (administration, interview, psychology test)

4) Actively undergoing PC training

5) Pass the exam after training 
The group activities that can be carried out at the Indonesian Penitentiary for TC are:

a. Morning Meeting

Namely routine activities every morning at 09.00 to $11.00 \mathrm{WIB}$ in the form of a meeting of the whole family to convey important things that happen in their block environment.

The procedures for implementing the Morning Meeting are:

1) The whole family gathered in a place / room

2) Family stands in a circle and joins hands to

3) After finishing reading serenity prayer, all the residents embrace to read philosophy led by one resident and followed by another resident

4) The family sits in a circle in a $U$ shape with the older status structure at the end of the circle

5) In the center of the end of the circle two chairs are provided for a conductor (major on duty) and a C.O.D. / On Chair (C.O.D. on duty that day)

6) Morning Meeting starts with the announcement session, followed by awareness; pull ups, interruption, issues, and ends with the second half. Second half consists of up lifter rituals, games, weather forecasts, and news.

7) After the second half continues with the reading process observer, the formation of the theme of the day

b. Morning Briefing

Is an activity that discusses various matters relating to TC activities for 1 week carried out on weekends. The goal is to increase honesty among family.

\section{c. Open House}

Namely the inspection activities and search of residential rooms (blocks) of resident TC to see the condition of the room both in terms of cleanliness, tidiness and any violations committed by residents. This activity is carried out incidentally (at any time), led by a counselor and assisted by an older status.

\section{d. Encounter Group}

Namely an activity specifically designed to express feelings of annoyance, disappointment, sadness, concern (concern), and others. This activity is an activity of shaping emotional behavior and regulation to be more disciplined and directed.

Purpose of Encounter Group:

1) Creating a healthy and dynamic community life

2) Make a personal community responsible

3) Cultivate the courage to express feelings

4) Building discipline Learn to direct emotions properly and correctly without causing resentment The procedure for implementing Encounter Group:

1) The resident sits in a circle

2) In the middle of the circle is positioned two chairs facing each other with a certain distance $( \pm$ $1.5 \mathrm{~m})$

3) A conductor (facilitator / one of the major) leads the prayer before starting the activity

4) Conduct guides residents to mention the Rules of Encounter one by one in turn

5) Families who enter the drop slip / have the feeling of sitting in a chair that is provided in turn 
6) Families who have these feelings do a running feeling / channel their anger to the intended resident / drop slip

7) After all the families that drop slips do a running feeling, the conduct gives feedback

8) The activity was closed by reading a prayer led by conduct After everything is finished, it ends with shaking hands and hugging each other

e. Static Group

Is an activity in the form of small groups that discuss various kinds of problems of daily life and past lives? In Static activities, each group is facilitated by a counselor who builds a comfortable atmosphere and trust among fellow residents.

Purpose of Static Group:

1) Build trust between fellow residents and counselors

2) Image breaking (open yourself up with arousing trust in the environment)

3) Foster a sense of moral responsibility towards the problems of his friends

4) Together looking for the right problem solving solution

The procedure for implementing Static Group:

1) Family is divided into small groups led by a static (peer counselor)

2) Each group sits in a circle

3) The activity begins with reading the prayer led by the counselor, where all residents in each group join hands

4) The group starts sharing their personal problems, followed by confrontation (question and answer) and giving feedback by each group member / counselor The event closed with a prayer and ended with a handshake and hugging each other

f. P.A.G.E. Group (Peer Accountability Group Evaluation)

Is an activity that teaches residents to be able to provide positive and negative assessments of the behavior and attitudes of other residents in everyday life. In this activity residents are trained to increase sensitivity and concern for community behavior.

Purpose of PAGE Group:

1) Resident gets honest input on his attitude and behavior while undergoing TC

2) Resident realizes the weaknesses and strengths so that the bias can do introspection

3) Awaken confidence

4) Build a healthy community by caring for one another

g. Mix Confrontation

Does a resident express exploring a problem. The purpose of this activity is the emergence of "insight" on the resident's self from the questions raised by other residents. Mix confrontation rules:

1) Resident is only allowed to ask questions

2) May not provide feedback

3) Questions should be something that gives rise to "insight"

h. Seminar

The activities in the form of providing material related to TC, drugs, and other relevant knowledge. The aim is to open up insights and foster self-awareness of the dangers of drugs. This activity was followed by the TC family with PC (Peer Counselor) material providers, Major, as well 
as officials in the Jakarta Narcotics Prison environment, the Jakarta Narcotics OSC Integrated T\&R team and other interested parties.

i. Sport and Recreation

This activity reduces the level of stress experienced by residents during the activity. Sports activities include mass gymnastics, soccer, volleyball and basketball. While recreation activities in the form of music / band and video session, namely watching a movie together.

j. Older Status Formation

This activity serves to shape the soul of leadership and enhance a sense of responsibility towards oneself and the environment. Job changes are determined by the staff by taking into account the progress of each resident. Older status in Jakarta Narcotics Prison consists of Chief, Shingle, HOD (House of Department), and expeditor.

k. Function

Function activities are activities carried out in order to increase the sense of responsibility and concern for the cleanliness of the surrounding environment. This activity is scheduled every day and is carried out before and after group activities.

1. Religious Session

Is an activity that is directed at self-deepening of the spiritual and religious life. This activity is carried out every Friday afternoon. In addition to group activities, sanctions are also carried out in the program. Sanctions are given to residents who make mistakes or do negative things. This activity is carried out in stages according to the mistakes made. To get these sanctions, the resident first undergoes a reprimand session. Sessions conducted are:

1) Spoken to: Subtle rebuke and gentle advice given to residents for their negative behavior. Usually given by COD or by PC.

2) Dealt with: Reprimand given for frequent repeating the same mistakes. This reprimand was given by a panelist team led by a facilitator. From this session the resident was only given awareness.

3) Haircut: Reprimand is given loudly to a resident because of repeated mistakes also given to residents who violate the rules. This reprimand was given by a panelist team led by a facilitator. From this session the resident can be sanctioned.

4) Family haircut: Strong reprimand from family to residents who make repeated mistakes. This session was attended by all residents and each resident representative gave a warning led by the facilitator. From this session the resident was given LE.

5) General Meeting: Strong reprimands to residents for violating Cardinal Rules. Given by all families jointly led by the facilitator.

For the panelist who runs a dealt with session and haircut consists of:

1) Facilitator: who leads the session

2) Confront: Give questions related to fumble

3) Blast: Rebuke hard (give direction) without giving hope and feedback

4) Sarcastic: Give a reprimand in the form of satire or sarcastic reprimands

5) Catchup: Deliver statements subtly, and provide hope and feedback

6) After undergoing the session, the residents are given outcomes. Outcomes can be in the form of awareness, tasks, and LE (learning experiences).

m. Learning Experience

These are forms of sanctions given after undergoing reprimand sessions. The form of sanctions is directed at changing attitudes, ways of thinking, discipline and self-evaluation of his mistakes. 
The goal of LE is for residents to learn from their experiences to be able to change behavior. The types of LE ranging from the lightest to the heaviest are:
1) LE others
2) LE pots ink
3) LE ground
4) LE spare part
5) LE Extracurricular / limbo

\section{B. Barriers in the Implementation of Therapeutic Community Against Drug Prisoners}

Some barriers in implementing the program includes:

a) The minimum number of correctional officers who have knowledge of drug abuse rehabilitation programs during the implementation of narcotics rehabilitation is very minimal role for correctional institution officers, because in this process officers are not adequately equipped. This should have education taking part in narcotics rehabilitation training and basic training for officers to add knowledge and insight to TCs in implementing the program.

b) Facilities and infrastructure that must be met in conducting therapeutic community (TC) in correctional institution in Indonesia. This happens because of several factors including the budget to build or renovate the room does not yet exist and the increasing number of prisoners, causing a narrow room. The increase of prisoners in correctional institution (LAPAS) Indonesia is not supported by the existing budget, so the therapeutic community (TC) program

\section{Conclusion}

This study concludes that (1) implementation of a therapeutic community program (TC) for prisoners in prison in the case of narcotics in prisons in Indonesia which is well implemented has an impact on the minimum of existing problems, to make this program successful, synergy with other institutions and the community is needed, and (2) the implementation of community therapeutic (TC) programs which are currently being carried out in prison and drug rehabilitation institutions still have some, these obstacles interfere with the effectiveness of the program. Synergy is needed for all parties to take part in making this program run effectively. Subsequent studies on what are the most important constraints and how the solution is still needed.

\section{References}

Aditya Sarjana Putra, 2017, Bimbingan Pasca Rehabilitasi Klien Pemasyarakatan Tindak Pidana Narkotika, Jurnal Hukum Khaira Ummah UNISULLA Semarang

Andrika Aditia, 2019, Ibra Azhari 4 Kali Ditangkap Kasus Narkoba Dan Terancam Hukuman Berat, (Online) Lihat di: https://www.kompas.com/hype/read/2019/12/24/115258066/ibra-azhari-4-kaliditangkap-kasus-narkoba-dan-terancam-hukuman-berat?page=all

Babor, T. F., Caulkins, J. P., Edwards, G., Fischer, B., Foxcroft, D. R., Humphreys, K., ... \& Rossow, I. (2010). Drug policy and the public good. Oxford University Press.

Dedi Humas, Mengenal Therapeutic Community, (Online), http://Dedihumas. Bnn.Go Indonesia, Undang-Undang Republik Indonesia Nomor 12 Tahun 1995 tentang Pemasyarakatan. Indonesia, Undang-Undang Republik Indonesia Nomor 35 Tahun 2009 tentang Narkoba.

Ismail, W., Mokhtar, M. K., Subhi, N., \& Ibrahim, F. (2015). Descriptive Analysis the Profile of Drug Abuse among Adolescents. Scientific Journal of PPI-UKM, 2(2), 77-85.

Jacobs, J. B. (2015). Stateville: The penitentiary in mass society. University of Chicago Press. 
Mohammad Fikri Haiqal, 2016, Peran Balai Pemasyarakatan Dalam Mengembalikan Fungsi Sosial Terhadap Klien Anak Sebagai Warga Binaan Pemasyarakatan (Narapidana), Jurnal Fakultas Hukum Universitas Lampung Bandar Lampung.

Moleong, J. L. (2005). Metodologi penelitian kualitatif, edisi revisi bandung: remaja Rosdakarya.

Morrison, C., Kurniasih, Y., \& Barton, G. (2012). The landscape of services for drug users in Yogyakarta, Indonesia. Drug and alcohol review, 31(1), 95-100.

Muhammad Nasir, mohd Din \& Dahlan Ali, 2013, Perspektif Kebijakan Hukum Pidana Terhadap Narapidana Yang Melarikan Diri Pada Saat Menjalani Pidana, Jurnal Ilmu Hukum Pasca Sarjana Universitas Syiah Kuala.

Muridan, 2015, Menumbuhkan Rasa Percaya Diri Melalui Peningkatan Soft Skill Dan Life Skill Bagi Narapidana Menjelang Bebas Bersyarat Di Balai Pemasyarakatan (BAPAS) Purwokerot, (Online) Lihat di: https://books.google.co.id/books/about/Menumbuhkan Rasa Percaya Diri Melalui Pe.html?hl=i $\mathrm{d} \& \mathrm{id}=$ RoSYDwAAQBAJ\&redir_esc $=\mathrm{y}$

Nurfatiha, D. (2015). Juridical Analysis Toward Parole Release For Graft Inmates (Case Study: Ministerial Decree Of Law And Human Right Of The Republic Of Indonesia Number M. HH-26. PK. 01.05. 06 YEAR 2014 On Behalf Of Siti Hartati Mudrdaya) (Doctoral dissertation, President University).

Poerwandari, K. (2001). Pendekatan Kualitatif Dalam Penelitian Psikologi, Lembaga Pengembangan Sarana Pengukuran dan Pendidikan Psikologi. Fakultas Psikologi, Universitas Indonesia.

Ritchie, J., \& Spencer, L. (2002). Qualitative data analysis for applied policy research. In Analyzing qualitative data (pp. 187-208). Routledge.

Ronaldo Chaniago, 2019, Kepala BNN: Pengguna Narkoba pada 2019 Tembus 3,6, (Online) Lihat di: https://m.liputan6.com/news/read/4127338/kepala-bnn-pengguna-narkoba-pada-2019-tembus-36juta-orang

Susanto, D. B. (2013). Pola Pelaksanaan Bimbingan Narapidana Selama Pembebasan Bersyarat untuk Tidak Melakukan Tindak Pidana (Studi di Balai Pemasyarakatan Klas I Malang). Kumpulan Jurnal Mahasiswa Fakultas Hukum, 1(2).

Thomas, E., \& Magilvy, J. K. (2011). Qualitative rigor or research validity in qualitative research. Journal for specialists in pediatric nursing, 16(2), 151-155.

Timan, I. S., Aulia, D., Atmakusuma, D., Sudoyo, A., Windiastuti, E., \& Kosasih, A. (2002). Some hematological problems in Indonesia. International journal of hematology, 76(1), 286-290.

Wibawa, A., Utami, Y. S., \& Fathonah, S. (2017). Pola Komunikasi Konselor dan Narapidana. Jurnal ASPIKOM, 2(6), 410-424.

Widiawaty,L. (2019). Proses Bimbingan Klien Pemasyarakatan Melalui Penerapan Rohani Islam Dalam Kemandirian Spiritual Di Balai Pemasyarakatan Kelas I Cirebon, Artiel Fakultas Ushuluddin Adab Dakwah (FUAD) IAIN Syekh Nurjati Cirebon.

Yustinus Semiun, O. F. M. (2006). Kesehatan mental 3. Kanisius.

Article Information (Supplementary)

Conflict of Interest Disclosures:

The authors declare that they have no significant competing financial, professional or personal interests that might have influenced the performance or presentation of the work described in this manuscript.

Copyrights Holder: $<$ Putra $><2020>$

First Publication Right: BISMA The Journal of Counseling

http://dx.doi.org/10.23887/bisma.v3i1

Open Access Article | CC-BY Creative Commons Attribution 4.0 International License.

@creative

Word Count: 3997 